\title{
Using ammonium-tolerant yeast isolates: Candida halophila and Rhodotorula glutinis to treat high strength fermentative wastewater
}

\author{
Q. Yang , M. Yang , L. Hei \& S. Zheng
}

To cite this article: Q. Yang , M. Yang , L. Hei \& S. Zheng (2003) Using ammonium\#tolerant yeast isolates: Candida halophila and Rhodotorula glutinis to treat high strength fermentative wastewater, Environmental Technology, 24:3, 383-390

To link to this article: http://dx.doi.org/10.1080/09593330309385571

曲 Published online: 17 Dec 2008.

Submit your article to this journal

Џ Article views: 44

Q View related articles $\longleftarrow$

Citing articles: 18 View citing articles 질 


\title{
USING AMMONIUM-TOLERANT YEAST ISOLATES: CANDIDA HALOPHILA AND RHODOTORULA GLUTINIS TO TREAT HIGH STRENGTH FERMENTATIVE WASTEWATER
}

\author{
Q. YANG ${ }^{1,2}$, M. YANG ${ }^{1 *}$, L. HEI ${ }^{1}$ AND S. ZHENG ${ }^{1}$
}

\begin{abstract}
${ }^{1}$ State Key Laboratory of Environmental Aquatic Chemistry, Research Center for Eco-Environmental Sciences, Chinese Academy of Sciences, P.O. Box 2871, Beijing 100085, China

${ }^{2}$ College of Life Sciences, Henan Normal University, Xinxiang Henan 453002, China
\end{abstract}

(Received 20 February 2002; Accepted 9 September 2002)

\begin{abstract}
Two ammonium-tolerant yeast strains were isolated from sludge samples contaminated with monosodium glutamate manufacturing wastewater and were identified as Candida haplophila and Rhodotorula glutinis. The tolerance of the two yeast isolates to ammonia and their chemical oxygen demand (COD) removal performances were evaluated under batch and bench-scale conditions. The mixture of the two isolates was found to grow well in an artificial medium containing $25 \%$ $\left(\mathrm{NH}_{4}\right)_{2} \mathrm{SO}_{4}$ and could effectively remove $\mathrm{COD}$ from monosodium glutamate wastewater even when the concentrations of $\mathrm{NH}_{4}{ }^{+}-\mathrm{N}$ and free $\mathrm{NH}_{3}-\mathrm{N}$ reached as high as 18977 and $879 \mathrm{mg}^{-1}$ respectively. A fixed-bed yeast reactor, which was initially inoculated with the yeast mixture, permitted a constant COD removal rate of over $80 \%$ during a period of near 2-month continuous running even when the influent COD was increased from 8000 to $25000 \mathrm{mg} \mathrm{l}^{-1}$. The effluent was accompanied with suspended solids (SS) of over $4500 \mathrm{mg} \mathrm{l}^{-1}$, which was mainly composed of yeast cells and could be considered as a source of animal forage additive. The residual $\mathrm{COD}$ of effluents from the yeast reactor could be further reduced to under 500 $\mathrm{mg} \mathrm{l}^{-1}$ by a combination process of activated sludge treatment and coagulation technologies.
\end{abstract}

Keywords Yeast, monosodium glutamate (MSG), wastewater treatment, ammonium

\section{INTRODUCTION}

In China, there are more than 600 monosodium glutamate (MSG) manufacturing plants producing nearly 1 million ton MSG annually. MSG wastewater is characterized by high concentrations of chemical oxygen demand (COD) (10000-30000 $\mathrm{mg} \mathrm{l}^{-1}$ ), ammonium (15000-25000 $\left.\mathrm{mg} \mathrm{l}^{-1} \mathrm{NH}_{4}^{+}-\mathrm{N}\right)$, and sulfate (15000-30000 $\mathrm{mg} \mathrm{l}^{-1}$ ), which makes it very difficult to be treated with conventional biological treatment processes in spite of the high biochemical oxygen demand (BOD) to $C O D$ ratio $(>0.8)$. Anaerobic techniques are believed to be one of the most efficient processes for treating high strength organic wastewater. However, the toxic inhibition of ammonia took place to most anaerobes in spite of $\mathrm{pH}$ control when the concentration of $\mathrm{NH}_{4}{ }^{+}-\mathrm{N}$ was higher than $3000 \mathrm{mg} \mathrm{l}^{-}$ ${ }^{1}$ [1]. The conventional aerobic process was also significantly affected by high concentration of $\mathrm{NH}_{4}{ }^{+}-\mathrm{N}$. Li et at [3] and Zhao [3] reported that the COD removal in an activated sludge process declined from 95.1 to $78.1 \%$ when the $\mathrm{NH}_{4}{ }^{+}-\mathrm{N}$ concentration was increased from 50 to $800 \mathrm{mg} \mathrm{I}^{-1}$. The common practice in China is to dilute wastewater to eliminate the microbial inhibitions caused by high concentrations of ammonia or sulfate [4-6], which resulted in high operation costs and waste of precious water resources. Therefore, a technique employing microorganisms that can tolerate high strengths of $\mathrm{NH}_{4}^{+}-\mathrm{N}$ and sulfate is required to solve the problem.

From the 1970s, there have been many reports on the application of yeast to wastewater treatment under aerobic and open conditions [7-10]. Compared with the conventional biological wastewater treatment process in which bacteria are predominant, yeast treatment technology which permits a high COD load and endures high osmotic pressure makes it a promising alternative for treating MSG wastewater. In this study, yeast isolates capable of growing directly in MSG wastewater were obtained through screening and their tolerance to ammonia and COD removal performances were evaluated under batch and bench-scale conditions.

MATERIALS AND METHODS

\section{Wastewater Characterization}

The characteristics of MSG wastewater samples 
collected from an MSG manufacturing factory in Tianjin, China are shown in Table 1 . It is obvious that the sample contained high concentrations of $\mathrm{COD}, \mathrm{NH}_{4}{ }^{+}-\mathrm{N}, \mathrm{SO}_{4}{ }^{2}$, suspended solids (SS), and the $\mathrm{pH}$ was low.

Table 1. Characteristics of MSG wastewater.

\begin{tabular}{lc}
\hline Determination items & Concentration $\left(\mathrm{mg} \mathrm{l}^{-1}\right)$ \\
\hline COD & 24125 \\
Total organic carbon & 7411 \\
$\mathrm{BOD}_{5}$ & 18000 \\
$\mathrm{SS}$ & 1200 \\
Total phosphate & 37.3 \\
$\mathrm{SO}_{4}^{2-}$ & 20706 \\
$\mathrm{NH}_{4}{ }^{+} \mathrm{N}$ & 18977 \\
Protein $_{\text {Reducing sugar }}$ & 960 \\
Total sulphur & 5981 \\
pH & $12 \%$ \\
Temperature & 2.0 \\
\hline
\end{tabular}

Analytical Methods

COD, TOC, SS, $\mathrm{NH}_{4}{ }^{+}-\mathrm{N}, \mathrm{SO}_{4}{ }^{2-}$ and total phosphate (TP) were determined according to Standard Methods [11]. The concentration of soluble protein was detected by Bradfords method [12] and the reducing sugar was determined according to 3,5-Dinitrosalicylic acid method (DNS method) [13]. The ratio of $\mathrm{NH}_{3}$ to $\mathrm{NH}_{4}^{+}$is $\mathrm{pH}$ and temperature dependent of the solution. The un-ionized ammonia fractions $\left(\mathrm{NH}_{3}\right)$ were calculated by the concentrations of $\mathrm{NH}_{4}{ }^{+}-\mathrm{N}$ in the solution [14].

\section{Media for Yeast Isolation and Preservation}

Selective medium 1: glucose $20 \mathrm{~g}$, yeast extract powder $5 \mathrm{~g}$, peptone $10 \mathrm{~g}$, sodium propionate $0.25 \%$, agar powder $2 \%$, tap water $1000 \mathrm{ml}, \mathrm{pH} \mathrm{4.5}$, adding streptomycin to $30 \mathrm{mg} \mathrm{l}^{-1}$ just before use. This medium was used for yeast screening.

Selective medium 2: MSG wastewater sample $1000 \mathrm{ml}$, sodium propionate $0.25 \%$, agar powder $2 \%, \mathrm{pH} 4.5$, adding streptomycin to $30 \mathrm{mg} \mathrm{l}^{-1}$ just before use. This medium was used for yeast screening.

YPD medium: glucose $20 \mathrm{~g}$, yeast extract powder $5 \mathrm{~g}$, peptone $10 \mathrm{~g}$, agar powder $2 \%$, tap water $1000 \mathrm{ml}$, pH 4.5 . This medium was used for yeast cultivation and preservation.

Nitrogen free minimal medium: glucose $20 \mathrm{~g}, \mathrm{~K}_{2} \mathrm{HPO}_{4} 1$ g, $\mathrm{MgSO}_{4} \cdot 7 \mathrm{H}_{2} \mathrm{O} 0.5 \mathrm{~g}$, yeast extract powder $0.1 \mathrm{~g}$, distilled water $1000 \mathrm{ml}$, pH 7.0. This medium was used for evaluating the endurance of yeast to $\left(\mathrm{NH}_{4}\right)_{2} \mathrm{SO}_{4}$.

\section{Enrichment, Isolation, and Identification}

Yeast enrichment and isolation were followed by the methods proposed by Chigusa et al. [10]. Sludge samples were collected from several spots contaminated with MSG wastewater. One gram of sludge sample was inoculated into $150 \mathrm{ml}$ MSG wastewater whose $\mathrm{pH}$ was adjusted to 4.5-5.0, and cultivated at $28^{\circ} \mathrm{C}, 170 \mathrm{rpm}$ on a reciprocal shaker. Half volume of the culture was removed and supplemented with new MSG wastewater once a day. After enrichment cultivation for 10 days, $10 \mathrm{ml}$ of the culture was transferred to $150 \mathrm{ml}$ new MSG wastewater containing $30 \mathrm{mg} \mathrm{l}^{-1}$ streptomycin and cultivated for 2 days. Then $0.2 \mathrm{ml}$ of the culture was transferred to agar plates containing selective medium 1 and selective medium 2 respectively and cultivated for another 2 days. Yeast colonies with different shapes were selected from the agar plates and repeatedly transferred onto new plates until the cultures were pure. Stock cultures were stored on YPD plates at $4^{\circ} \mathrm{C}$ and periodically subcultured.

Yeast strains isolated by the above procedure were identified according to their respective morphological and physiological characteristics under different carbon or nitrogen sources [15].

\section{Endurance of Isolates to Ammonia}

The endurance of mixed isolates to different strengths of ammonia-nitrogen was tested in both sterile artificial medium and nonsterile actual wastewater. The nitrogen free minimal medium was added with $\left(\mathrm{NH}_{4}\right)_{2} \mathrm{SO}_{4}$ to obtain an $\left(\mathrm{NH}_{4}\right)_{2} \mathrm{SO}_{4}$ concentration varying from 0.5 to $50 \%$ and sterilized by bacteriological filters (pore size, $0.4 \mu \mathrm{m}$ ). MSG wastewater containing $18977 \mathrm{mg} \mathrm{I}^{-1}$ of $\mathrm{NH}_{4}{ }^{+}-\mathrm{N}$ was diluted by the ratios of $1: 9,1: 2$ and 1:1 to achieve different ammonianitrogen strengths. One milliliter of mixed yeast culture from liquid YPD medium was used as inoculum. Flasks were prepared in triplicate for each gradient and incubated at $28^{\circ} \mathrm{C}$, $170 \mathrm{rpm}$ in a shaker. Samples were taken periodically. The growth of yeast in artificial medium was evaluated by measuring the absorbance at $660 \mathrm{~nm}$ on a spectrophotometer, and the growth in MSG wastewater was determined by assaying mixed liquor suspended solids (MLSS).

Effect of Initial pH on COD Removal of MSG Wastewater by Isolates

Mixed yeast culture of $10 \mathrm{ml}$ from YPD medium was inoculated into $100 \mathrm{ml}$ diluted MSG wastewater (1:9) of which the $\mathrm{pH}$ was adjusted to 2.0-9.0. Flasks were prepared in triplicate for each $\mathrm{pH}$ gradient and cultivated in a reciprocal shaker at $28^{\circ} \mathrm{C}, 170 \mathrm{rpm}$ for $48 \mathrm{~h}$ under nonsterile conditions. Samples were taken periodically to assay the COD variation.

\section{Batch Treatment of MSG Wastewater by Isolates}

One liter wastewater with various dilution ratios (1:9, 1:2, 1:1 and raw wastewater) was respectively inoculated with wet yeast cells at the inoculum of MLSS to COD, 1:1.5 and cultivated at $28^{\circ} \mathrm{C}, \mathrm{pH} 4.5$ in a 2 l-tank under nonsterile 
conditions. Air was supplied with an air pump controlled by an air flow meter, and samples were taken periodically for COD measurement.

Bench Scale Treatment System

Ethylene fibers (5 $\mathrm{cm}$ in length) fixed on plastic rings ( $\phi$ $5 \mathrm{~cm}, 10 \mathrm{~cm}$ between the neighboring rings) were hung in a lucite cylindrical column (effective volume of 12.21 ) as biocarriers (shown as Figure 1). The column was continuously fed with diluted wastewater (1:9) from the bottom after 11 mixed yeast culture was inoculated to the column reactor. The reactor was thermo-regulated at $28^{\circ} \mathrm{C}$ and operated at a hydraulic retention time (HRT) of $40 \mathrm{~h}$. Air was supplied from the bottom of the reactor with an air pump controlled by a flow meter. In all the steady state runs, the dissolved oxygen concentration (DO) in the reactor was controlled to a range of 2-4 $\mathrm{mg} \mathrm{l}^{-1}$ to ensure an aerobic treatment. The strength of wastewater was gradually increased through decreasing the dilution ratio of wastewater after the COD removal of effluent was stable. Table 2 shows operation conditions.

\section{RESULTS AND DISCUSSION}

\section{Characteristics and Identification of Isolates}

Two strains of yeast (WG1 and WG2) were isolated and purified. The morphological and physiological characteristics of every single isolate were studied and their abilities of utilizing different organics as sole carbon or nitrogen source were detected (shown in Table 3). According to the method proposed by Barnett et al. [15], WG1 and WG2 were identified as Candida haplophila and Rhodotorula glutinis, respectively. Considering mixed strains are more suitable for practical application, the two yeasts were cultured together as seed yeast for the following tests.

Endurance of Mixed Yeast to Ammonia

To evaluate the tolerance of the two isolates to ammonia-nitrogen, the kinetic behaviors of Candida haplophila and Rhodotorula glutinis growing in different concentrations of $\left(\mathrm{NH}_{4}\right)_{2} \mathrm{SO}_{4}$ were investigated in both sterile artificial medium and nonsterile wastewater. The results are shown in Figure 2 (a) and (b).

From Figure 2 (a), it was found that the mixed yeast strains grew at the maximum rate before $24 \mathrm{~h}$ when the concentration of $\left(\mathrm{NH}_{4}\right)_{2} \mathrm{SO}_{4}$ was in a range of $0.5-5 \%$ (i.e., 1029.6-10296 $\left.\mathrm{mg} \mathrm{l}^{-1} \mathrm{NH}_{4}{ }^{+}-\mathrm{N}\right)$. The growth rate showed a small decrease when the dose of $\left(\mathrm{NH}_{4}\right)_{2} \mathrm{SO}_{4}$ was increased to $10 \%$ (20592 $\mathrm{mg} \mathrm{l}^{-1} \mathrm{NH}_{4}{ }^{+}-\mathrm{N}$ ) and a significant repression of yeast growth was observed under $25 \%\left(\mathrm{NH}_{4}\right)_{2} \mathrm{SO}_{4}\left(51476 \mathrm{mg} \mathrm{l}^{-1}\right.$ $\left.\mathrm{NH}_{4}{ }^{+}-\mathrm{N}\right)$. The two yeast strains couldn't grow under $30 \%$ $\left(\mathrm{NH}_{4}\right)_{2} \mathrm{SO}_{4}$ over a period of $48 \mathrm{~h}$. Therefore, a concentration of $25 \%\left(\mathrm{NH}_{4}\right)_{2} \mathrm{SO}_{4}$ might be the upper limit for the growth of the yeast mixture. Few reports were found about the effects of $\mathrm{NH}_{4}{ }^{+}-\mathrm{N}$ on the growth of aerobic bacteria. Inhibition of anaerobic bacteria under high ammonia concentrations,

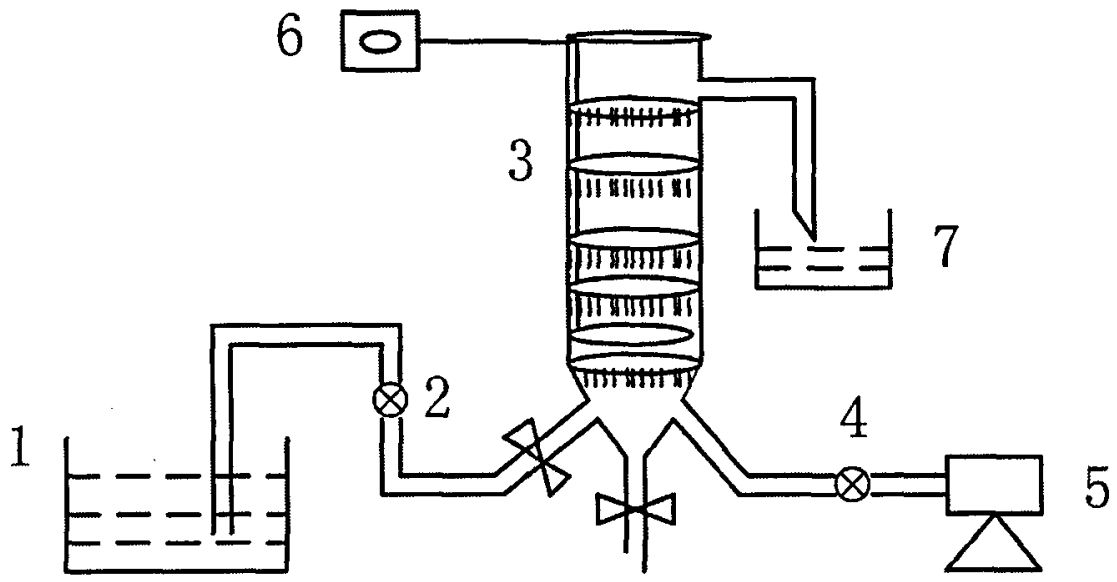

Figure 1. Yeast treatment system for MSG wastewater (1. Feed tank, 2. Volumetric pump, 3. Biofilm column reactor, 4. Air flow meter, 5. Air pump, 6. Thermoregulator, 7. Effluents).

Table 2. Operation conditions of bench-scale test.

\begin{tabular}{llllll}
\hline $\begin{array}{l}\text { Feeding rate } \\
\left(1 \mathrm{~d}^{-1}\right)\end{array}$ & $\begin{array}{l}\text { Influent COD } \\
\left(\mathrm{mg} \mathrm{l}^{-1}\right)\end{array}$ & $\begin{array}{l}\text { Influent } \\
\mathrm{pH}\end{array}$ & $\begin{array}{l}\text { Air flow } \\
\left(1 \mathrm{~min}^{-1}\right)\end{array}$ & HRT (h) & $\begin{array}{l}\text { Temperature } \\
\left({ }^{\circ} \mathrm{C}\right)\end{array}$ \\
\hline 7.2 & $8000 \sim 25000$ & $2.0 \sim 3.0$ & $30 \sim 100$ & 40 & 28 \\
\hline
\end{tabular}


Table 3. Characteristics and identification of isolates.

\begin{tabular}{|c|c|c|c|c|c|}
\hline Items & WG1 & WG2 & Items & WG1 & WG2 \\
\hline Morphological characteristics & & & Sucrose & - & + \\
\hline Vegetative cell & Budding & Budding & Maltose & - & + \\
\hline Size $(\mu \mathrm{m})$ & $2-4$ & $2-10$ & Cellobiose & + & + \\
\hline Filaments & - & - & Trehalose & + & + \\
\hline Characteristics in liquid medium & & & Lactose & - & - \\
\hline Membrane-forming & + & + & Melibiose & - & - \\
\hline \multirow[t]{2}{*}{ Spore-forming } & - & - & Raffinose & - & + \\
\hline & & & Melizitose & - & + \\
\hline Physiological characteristics & & & Soluble starch & - & - \\
\hline Sugar fermentation & & & D-xylose & - & + \\
\hline D-Glucose & + & - & L-Arabinose & - & - \\
\hline D-Galactose & + & - & D-Arabinose & - & \\
\hline Maltose & - & - & D-Ribose & - & - \\
\hline Sucrose & + & - & L-Rhamnose & - & - \\
\hline Lactose & - & - & Glycerol & + & + \\
\hline \multirow[t]{2}{*}{ Raffinose } & - & $\cdot$ & Erythritol & - & - \\
\hline & & & Ribitol & - & - \\
\hline Arbutin splitting & + & & Galactitol & - & - \\
\hline Vitamin-free medium & - & + & D-Mannitol & + & - \\
\hline Urea hydrolysis & - & + & D-Glucitol & - & \\
\hline Starch-like compounds & - & - & Salicin & + & \\
\hline \multirow[t]{2}{*}{ Growth at $37^{\circ} \mathrm{C}$} & - & - & DL-Lactate & - & \\
\hline & & & Succinate & + & + \\
\hline Assimilation & & & Citrate & + & + \\
\hline Galactose & + & + & Inositol & - & - \\
\hline Sorbin & - & & $\begin{array}{l}\text { Nitrate } \\
\text { assimilation }\end{array}$ & + & + \\
\hline Results of identification & & WG1: Car & da halophila & WG2: RH & glutinis \\
\hline
\end{tabular}

+ , positive reaction; - , negative reaction

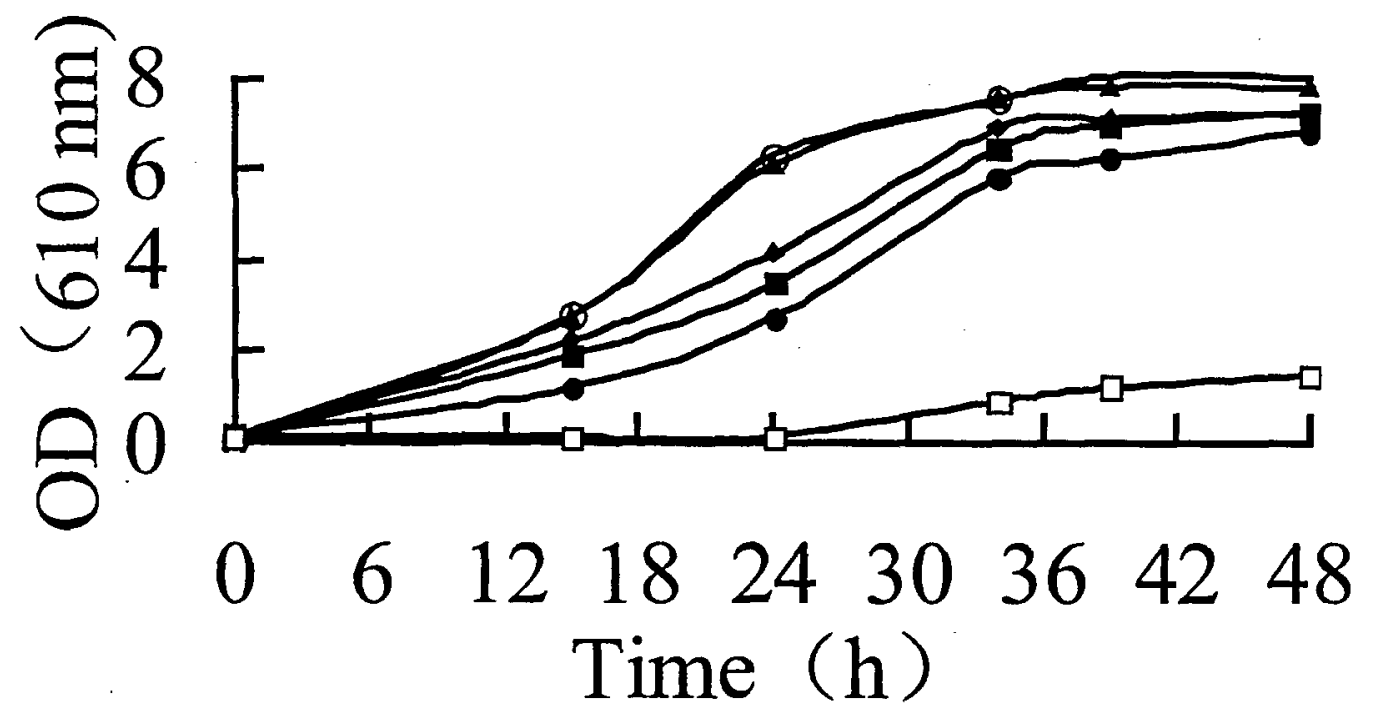

Figure 2a. Growth of mixed yeast in artificial medium containing different concentrations of $\left(\mathrm{NH}_{4}\right)_{2} \mathrm{SO}_{4}(\mathbf{O}, 0.50 \% ; \mathbf{\Delta}, 5 \%$; $\bullet, 10 \% ; \square, 15 \% ; 0,20 \% ; \square 25 \%)$. 


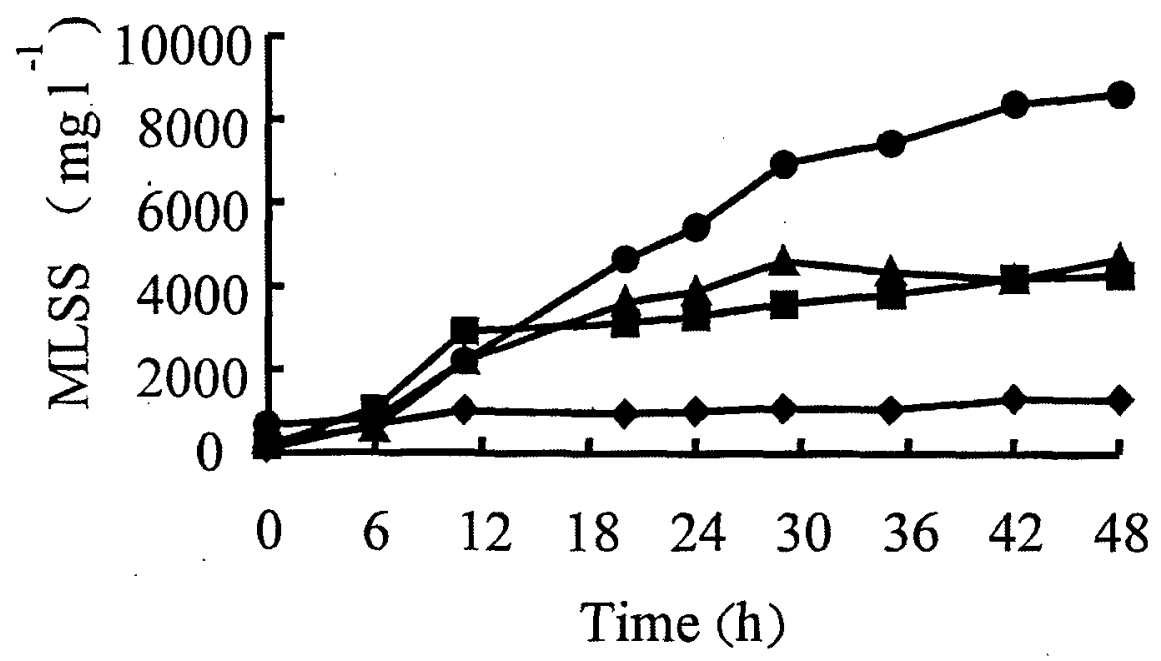

Figure $2 \mathrm{~b}$. Growth of yeast under different strength of MSG wastewater (wastewater to water) $(\bullet, 1: 9$ dilution; $\mathbf{\square}, 1: 2$ dilution; $\boldsymbol{\Delta}$, 1:1 dilution;, no dilution).

however, has often been reported. Anthonisen et al. [1] found that methane-forming bacteria were inhibited in spite of $\mathrm{pH}$ control when the total ammonia was over $3000 \mathrm{mg} \mathrm{l}^{-1}$. Therefore, the mixture of Candida haplophila and Rhodotorula glutinis could endure the total ammonia 3-17 times as high as the methane-forming bacteria.

Figure 2 (b) shows that the MLSS increased with time under each dilution ratio, and a higher MLSS corresponded to a lower dilution ratio. From Figure 2 (b), the kinetic trends of yeast growth under different dilution ratios were obtained. There was no noticeable lag phase of growth. Yeast went into fast growth phase immediately after inoculation, and then stopped into a stable phase (except for the case of no dilution). During the rapid growth phase, the growth rates of yeast were basically in proportion to the concentrations of COD in the solution. The higher the initial COD, the higher the growth rate. No significant inhibition of growth was observed even under the condition of no dilution $\left(18977 \mathrm{mg} \mathrm{l}^{-1} \mathrm{NH}_{4}{ }^{+}-\mathrm{N}\right.$, $20706 \mathrm{mg} \mathrm{r}^{-1} \mathrm{SO}_{4}{ }^{2-}$ ), indicating that Candida haplophila and Rhodotorula glutinis were suitable for treating MSG wastewater directly.

\section{Effect of $\mathrm{pH}$ on COD Removal}

The percent COD removals following $48 \mathrm{~h}$ treatment under different $\mathrm{pH}$ conditions were obtained and shown in Figure 3. According to Anthonisen et al. [1], the growth of microorganisms could be inhibited both by total ammonia and by free $\mathrm{NH}_{3}$, and the latter was far more toxic than $\mathrm{NH}_{4}^{+}$.

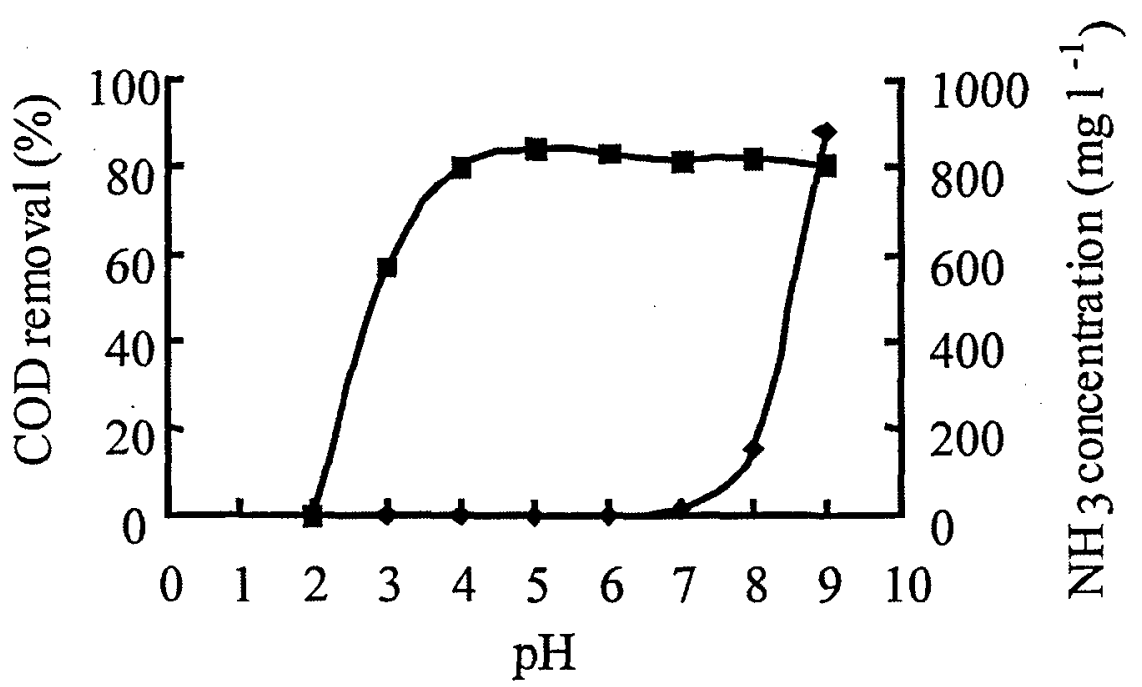

Figure 3. Effect of initial $\mathrm{pH}$ and $\mathrm{NH}_{3}$ concentration on $\mathrm{COD}$ removal $\left(\mathbf{\mathrm { Q }}, \mathrm{COD}\right.$ removal $\left.(\%) ; \bullet, \mathrm{NH}_{3}\left(\mathrm{mg} \mathrm{l}^{-1}\right)\right)$. 
It has been a well-known fact that the concentration of free $\mathrm{NH}_{3}$ in a solution was dependent on $\mathrm{pH}$, temperature and $\mathrm{NH}_{4}{ }^{+}$concentration. To evaluate the effect of $\mathrm{pH}$ and $\mathrm{NH}_{3}$ on COD removal, the concentration of free $\mathrm{NH}_{3}$ under each $\mathrm{pH}$ condition was also calculated and shown in Figure 3. The activities of yeast were almost completely inhibited at $\mathrm{pH} 2$, suggesting that a strong acidic condition was harmful to the yeast mixture. The $\mathrm{pH}$ effect was not noticeable in a $\mathrm{pH}$ range of 4-9, although the concentration of $\mathrm{NH}_{3}$ in the solution varied from 1.6 to $879.1 \mathrm{mg} \mathrm{l}^{-1}$. The percent COD removal was stable at more than $80 \%$. According to Anthonisen et al. [1], 10-150 mg l-1 of $\mathrm{NH}_{3}-\mathrm{N}$ was inhibitory to both nitrifying and heterotrophic bacteria. The result of Figure 3 further demonstrates that the tolerance of Candida haplophila and Rhodotorula glutinis to free $\mathrm{NH}_{3}$ was very strong. Since the $\mathrm{pH}$ of MSG wastewater was as low as 2, the initial $\mathrm{pH}$ in the following tests was adjusted to ca. 4 to ensure a final $\mathrm{pH}$ of 5 to 7 .

\section{COD Removal Under Different Dilution Ratios}

COD removals under different wastewater dilution ratios were investigated in a series of batch tests. The initial $\mathrm{pH}$ of every reactor was adjusted to 4.5 before the yeast mixture was inoculated. The inoculums were adjusted in proportion to COD concentrations to get similar reaction rates. Variations in COD concentrations as well as COD removal percent against time are plotted in Figure 4. It was found that the final COD removal was the same $84.5 \%$ when wastewater was diluted from 1:1 to $1: 9$ in spite of the large variations of the concentrations of $\mathrm{COD}$ and $\mathrm{NH}_{4}{ }^{+}-\mathrm{N}$. However, the percent COD removal for the solution without dilution was still increasing in the following 48-h treatment. From Figure 4, the COD decreasing rates $\left(\mathrm{mg} \mathrm{I}^{-1} \mathrm{~h}^{-1}\right)$ at any time could be acquired by regressing calculation. The initial COD decreasing rate was $240,552,631$ and $482 \mathrm{mg} \mathrm{l}^{-1} \mathrm{~h}^{-1}$ corresponding to wastewater with 1:9, 1:2, 1:1 dilution and no dilution. Except for the case without dilution, the initial COD decreasing rate was proportional to the initial COD concentration in the solution, indicating that the activities of yeast were not significantly affected by increasing COD and ammonia concentrations.

Variation of $\mathrm{pH}$ in one solution (1:1 dilution) during the treatment was measured every 6 hours. It was found that a sharp rise in $\mathrm{pH}$ occurred after $6 \mathrm{~h}$. By the time of $12 \mathrm{~h}$, the $\mathrm{pH}$ in the solution had increased from the initial value of 4.5 to 7.5 and then remained constant.

Table 4 shows variations of several other parameters before and after batch treatment. It is clear that there was a significant reduction in $\mathrm{COD}, \mathrm{BOD}_{5}$, total $\mathrm{P}$ and reducing sugar but a slight increase in $\mathrm{NH}_{4}{ }^{+}-\mathrm{N}$ and protein. The $\mathrm{BOD}_{5}$ removal of $99 \%$ indicates that almost all of the biodegradable

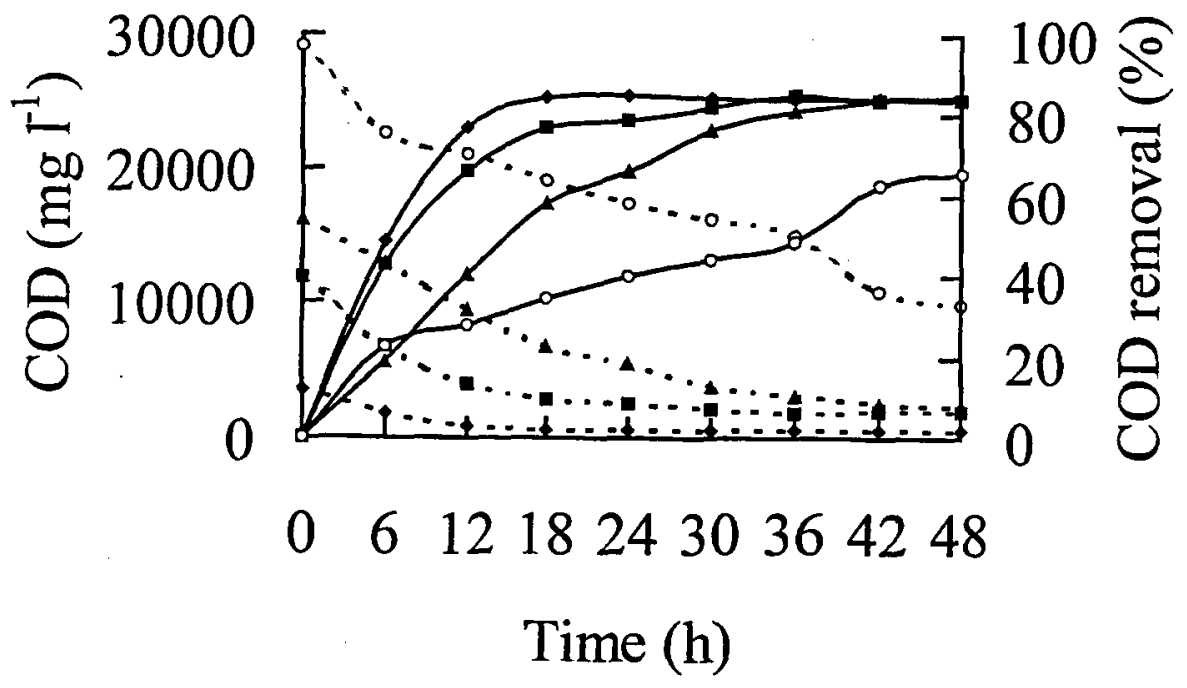

Figure 4. Variations of COD removal under different dilution ratios (wastewater to water) $(\bullet \bullet$, COD concentration; -, COD removal; $\bullet, 1: 9$ dilution; $\boldsymbol{\square}, 1: 2$ dilution; $\boldsymbol{\Delta}, 1: 1$ dilution; 0 , no dilution.

Table 4. Variations of several parameters before and after batch treatment by yeast $\left(\mathrm{g} \mathrm{I}^{-1}\right)$.

\begin{tabular}{llllllll}
\hline Test items & Wet cell $(\mathrm{g})$ & $\mathrm{COD}$ & $\mathrm{NH}_{4}{ }^{-} \mathrm{N}$ & $\mathrm{TP}$ & Protein & Reducing sugar & $\mathrm{BOD}_{5}$ \\
\hline Initial & 27.3 & 7.56 & 6.64 & 0.01 & 0.28 & 1.33 & 6.7 \\
After treatment & 39 & 1.22 & 6.68 & 0.005 & 0.36 & 0.05 & 0.069 \\
Removal rate $(\%)$ & & 84.5 & & 61.5 & & 96.5 & 99 \\
\hline
\end{tabular}


components in MSG wastewater were decomposed by yeast. The residual COD was perhaps contributed by fermentative intermediates produced in glutamate production, which are normally refractory to microorganisms. Considering the variation of $\mathrm{pH}$ before and after treatment, it suggested that the yeast strains mainly utilized small molecular organic acids and reducing sugar but couldn't use protein as their carbon sources. The increase of $\mathrm{NH}_{4}{ }^{+}-\mathrm{N}$ indicates that the residual glutamate in MSG wastewater was perhaps used as the main nitrogen source instead of $\mathrm{NH}_{4}{ }^{+}-\mathrm{N}$ by yeast.

\section{Bench Scale Treatment}

Variations of some important parameters for bench scale treatment system are shown in Figure 5 . It is clear that a stable COD removal over $80 \%$ was acquired over a period of nearly 2 months in spite of variation of influent COD from 8000 to $25000 \mathrm{mg} \mathrm{l}^{-1}$ and the concentration of $\mathrm{NH}_{4}{ }^{+}-\mathrm{N}$ from 6326 to $18977 \mathrm{mg} \mathrm{l}^{-1}$. It is interesting that good COD removal performance was maintained even for treating raw wastewater without dilution. The influent $\mathrm{pH}$ was adjusted to ca. 3.0 giving an effluent $\mathrm{pH}$ of 5.0 to 7.0 .

During days 50-57, the percent COD removal was almost unaffected even when the hydraulic retention time (HRT) was shortened from 40 to $30 \mathrm{~h}$ (the corresponding organic loading rate of the reactor increased from 10 to $18.7 \mathrm{~kg}$

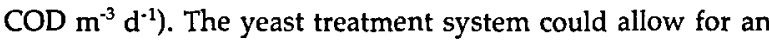
organic load rate (OLR) as high as $18.7 \mathrm{~kg} \mathrm{~m}^{-3} \cdot \mathrm{d}^{-1}$, which was nearly 10 times that of an aerobic membrane bioreactor (1-2

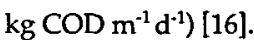

During the two months' operation of the yeast treatment system under nonsterile condition, the SS of effluent was also monitored every day (the values not shown here). The SS of effluent increased with the increasing of influent $C O D$, and was about $4500 \mathrm{mg} \mathrm{l}^{-1}$ when raw wastewater with a COD of $25000 \mathrm{mg} \mathrm{l}^{-1}$ was fed. Microscopic analysis showed that most of the cells in the effluents were yeast, indicating that yeast was dominant in the reactor. In other words, ca. $4.5 \mathrm{~g}$ yeast cells were obtained by decomposing $20 \mathrm{~g}$ of COD. Nourishment analysis indicates that dry yeast cells discharged with effluents contained $55.8 \%$ crude protein and 18 kinds of amino acids (values not shown here). These yeast cells could be separated from effluents and be used as an animal forage additive following proper treatment.

The effluents from the yeast reactor still contain nearly $5000 \mathrm{mg} \mathrm{l}^{-1} \mathrm{COD}$ and a very high concentration of $\mathrm{NH}_{4}-\mathrm{N}$. The residual $C O D$ of wastewater could be finally reduced under $500 \mathrm{mg} \mathrm{l}^{-1}$ by a combination of activated sludge treatment and coagulation process (Data not shown here). As for high concentration of ammonia in the effluents, conventional biological technologies are not suitable. The process of $\mathrm{NH}_{3}$ recovery and reuse to the production line using physicalchemical methods is seen as a desirable one. The facts that most $C O D$ was removed and the $\mathrm{pH}$ increased in the wastewater after treatment by yeast should be helpful to the treatment of $\mathrm{NH}_{4}-\mathrm{N}$.

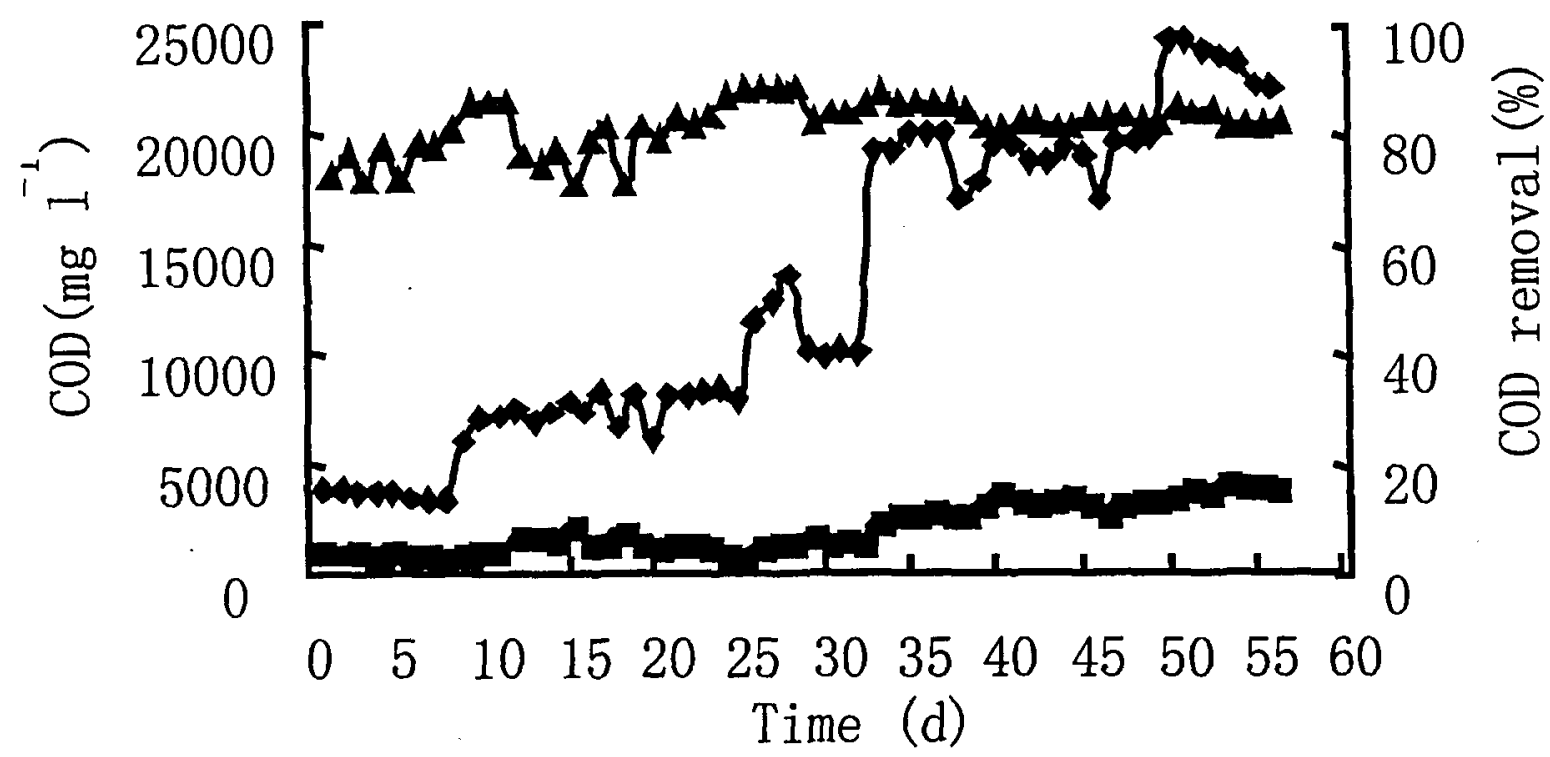

Figure 5. Variation of COD in bench scale treatment system $(\bullet$, influent $C O D ; \boldsymbol{\square}$, effluent $C O D ; \Delta, C O D$ removal). 


\section{CONCLUSIONS}

Two yeast isolates identified as Candida haplophila and Rhodotorula glutinis were isolated from sludge samples contaminated with monosodium glutamate manufacturing wastewater. Their mixture could endure as high as $25 \%$ $\left(\mathrm{NH}_{4}\right)_{2} \mathrm{SO}_{4}$ when cultivated in an artificial medium and could effectively remove COD of MSG wastewater without being significantly inhibited even when the concentrations of $\mathrm{NH}_{4}{ }^{+}$ $\mathrm{N}$ and free $\mathrm{NH}_{3}-\mathrm{N}$ reached as high as 18977 and $879 \mathrm{mg} \mathrm{l}^{-1}$, respectively.

In nearly 2 months of bench-scale continuous operation, stable yeast treatment of over $80 \%$ COD removal was maintained at a retention time of 30-40 h even when raw wastewater was fed and some important parameters were investigated. The effluents from the yeast reactor contained large concentrations of SS, ammonia and nearly $5000 \mathrm{mg} \mathrm{l}^{-1}$ residual COD. The SS of effluent most of which consisted of yeast cells was on average ca. $4500 \mathrm{mg} \mathrm{l}^{-1}$ when raw wastewater was fed and can be considered as animal forage additive. The residual COD in the effluents of the yeast reactor could be further reduced to under $500 \mathrm{mg} \mathrm{l}^{-1}$ by applying a combination process of activated sludge treatment and coagulation technology (data will be shown in another paper). Further study is required to remove $\mathrm{NH}_{4}-\mathrm{N}$ from effluents of the bioreactor.

\section{ACKNOWLEDGEMENTS}

The authors wish to acknowledge the committee of NSFC (National Science Foundation of China) for their support (No. 50078053).

\section{REFERENCES}

1. Anthonisen A., Loehr R., Prakasam T. and Srinath E., Inhibition of nitrification by ammonia and nitrous acid. J. Water Pollut. Control Fed., 48, 835-852 (1976).

2. Li X.Z., Zhao Q.L. and Hao X.D., Ammonium removal from landfill leachate by chemical precipitation. Wastewater Manage., 19, 409-415 (1999).

3. Li X.Z. and Zhao Q.L., Efficiency of biological treatment affected by high strength of ammonium-nitrogen in leachate and chemical precipitation of ammonium-nitrogen as pretreatment. Chemosphere, 44, 37-43 (2001).

4. Hui P., Anaerobic treatment of wastewater discharged from monosodium glutamate manufacturing by sulphuric acid method. Environ. Pollut. Prevent., 17, 10-13 (in Chinese) (1995).

5. Yang Q.I., Liu C. and Zhou Q., Treatment of wastewater discharged from monosodium glutamate manufacturing using UBF anaerobic reactor, Water $\mathcal{E}$ Wastewater, 22, 33-35 (in Chinese) (1996).

6. Chen L., Treatment of monosodium glutamate wastewater using SBR activated sludge. J Chinese Textile University, 22, 79-85 (in Chinese) (1996).

7. Yoshizawa K., Treatment of wastewater discharged from a Sake' Brewery using Yeast, J. Ferment. Technol., 56, 389-395 (1978).

8. Yoshizawa K., Development of the new treating method of wastewater from food industry using yeast, Nippon Nogeikagaku Kaoshi, 55, 705-711 (1981).

9. Moriya K., Iefuji H., Shimoi H., Sato S. and Tadenuma M., Treatment of distillery wastewater discharged from beet molasses-spirits production using yeast. J. Ferment. Bioeng., 69, 138-140 (1990).

10. Chigusa K., Hasegawa T., Yamamoto N. and Watanabe Y., Treatment of wastewater from oil manufacturing plant by yeasts. Water Sci. Technol., 34, 51-58 (1996).

11. APHA, Standard Methods for Water and Wastewater Examination, $19^{\text {th }}$ ed. American Public Health Association, Washington, D.C., USA Pp. 2-53 (1995).

12. Bradford M.M., A rapid and sensitive method for the quantitative analysis of microgram quantities protein utilizing the principle of protein dye binding. Anal. Biochem., 72, 248-254 (1976).

13. Biochemistry Group, Department of Biology, Beijing University, Experiment Instruction of Biochemistry, the People Education Press, Beijing, China (in Chinese), pp. 22-24 (1979).

14. Sabine K., Sanjeev K.D., Siemen V. and Vermaat J.E., The effect of $\mathrm{pH}$ variation at the ammonium/ammonia equilibrium in wastewater and its toxicity to Lemna gibba. Aquatic Botany, 71, 71-78 (2001).

15. Barnett J.A. Payne R.W. and Yarrow D., Yeasts: Characteristics and Identification (2 ${ }^{\text {nd }}$ ed). Cambridge University Press, New York, U. S. A., pp. 124-240 (1990).

16. Guender, B. and Krauth, Kh., Replacement of secondary clarification by membrane separation: results with plate and hollow fibre modules. Water Sci. Technol., 38, 383-393 (1998). 